\title{
Karst bare slope soil erosion and soil quality: a simulation case study
}

\author{
Q. Dai ${ }^{1}$, Z. Liu $^{2}$, H. Shao ${ }^{3,4}$, and Z. Yang ${ }^{1}$ \\ ${ }^{1}$ Forestry College of Guizhou University, Guiyang 550025, China \\ ${ }^{2}$ Anshun Xixiu District Water Conservancy Bureau, Anshun 561000, China \\ ${ }^{3}$ Key Laboratory of Coastal Biology \& Bioresources Utilization, Yantai Institute of Coastal Zone Research (YIC), \\ Chinese Academy of Sciences (CAS), Yantai 264003, China \\ ${ }^{4}$ Institute of Agro-Biotechnology, Jiangsu Academy of Agricultural Sciences, Nanjing 210014, China
}

Correspondence to: Q. Dai (qhdairiver@163.com) and H. Shao (shaohongbochu@126.com)

Received: 10 April 2015 - Published in Solid Earth Discuss.: 5 June 2015

Revised: 5 July 2015 - Accepted: 12 July 2015 - Published: 31 July 2015

\begin{abstract}
The influence on soil erosion by different bedrock bareness ratios, different rainfall intensities, different underground pore fissure degrees and rainfall duration are researched through manual simulation of microrelief characteristics of karst bare slopes and underground karst crack construction in combination with artificial simulation of rainfall experiment. The results show that firstly, when the rainfall intensity is small ( 30 and $50 \mathrm{~mm} \mathrm{~h}^{-1}$ ), no bottom load loss is produced on the surface, and surface runoff, underground runoff and sediment production are increased with the increasing of rainfall intensity. Secondly, surface runoff and sediment production reduced with increased underground pore fissure degree, while underground runoff and sediment production increased. Thirdly, raindrops hit the surface, forming a crust with rainfall duration. The formation of crusts increases surface runoff erosion and reduces soil infiltration rate. This formation also increases surface-runofferosion-damaged crust and increased soil seepage rate. Raindrops continued to hit the surface, leading the formation of crust. Soil permeability showed volatility which was from reduction to increases, reduction, and so on. Surface and subsurface runoff were volatile with rainfall duration. Fourthly, when rock bareness ratio is $50 \%$ and rainfall intensities are 30 and $50 \mathrm{~mm} \mathrm{~h}^{-1}$, runoff is not produced on the surface, and the slope runoff and sediment production present a fluctuating change with increased rock bareness ratio. Fifthly, the correlation degree between the slope runoff and sediment production and all factors are as follows: rainfall intensityrainfall duration-underground pore fissure degree-bedrock bareness ratio.
\end{abstract}

\section{Introduction}

Karst regions have surface and underground double-layer karst structures. A large amount of bedrocks are bared and the soil cover is not continuous. The heterogeneity of karst structure is great due to developed fissures, ponors and underground rivers. A part of water and soil enter the underground rivers along with the fissures and the ponors, so that water and soil loss in karst regions is classified into surface loss and underground soil leak, which have obvious difference compared with that in non-karst regions such as agricultural land reported by Cerdà et al. (2009a, b, 2010) and García-Orenes et al. (2009). In non-karst regions, soil erosion is mainly related to surface cover, slope, and rainfall conditions (Cerdà, 2000; Giménez et al., 2010; Biro et al., 2013; Haregeweyn et al., 2013) and it could be prevented if people take reasonable measures (Haile and Fetene, 2012; Prokop and Poręba, 2012; Mandal and Sharda, 2013). However, due to special geologic structure in karst regions, soil erosion is rather more complicated than that in non-karst regions.

In China, the area of the karst regions can reach 3.463 million $\mathrm{km}^{2}$ according to the distribution area of carbonate rocks (including buried karst), 2.06 million $\mathrm{km}^{2}$ according to the bared area of stratums containing carbonate rocks, and 0.907 million $\mathrm{km}^{2}$ according to the bared area of carbonate rocks; the southwest karst region in China is the biggest karst continuous region in the world (Sweeting, 1993). The soil erosion harm of karst mountainous areas is as great as the harm of Loess Plateau areas, so that enhancing the work of water and soil conservation in karst regions and governing the soil erosion of drainage basins are urgent. Nowadays, 
soil erosion that occurred in this region has caused serious soil and water losses and has become another important environmental problem after Loess Plateau of China (Zhao et al., 2013). For the past few years, a large amount of research on water and soil loss in karst regions has been performed, and certain achievements has been achieved.

Influence factors of karst bare slope runoff yield are mainly divided into three types: rainfall characteristics, drainage basin underlying surface and drainage basin evapotranspiration characteristics. Surface runoff process indicates a process in which rainfall with a capacity larger than slope soil infiltration capacity forms runoff on the surface; underground runoff indicates that rainfall flows into rivers after infiltrating into the an underground water-bearing layer, so as to form runoff. Atmospheric precipitation infiltration forms underground water or depression detention consumption; the slope can yield runoff only when the rainfall capacity is larger than the underlying surface consumption or the rainfall intensity is larger than the soil infiltration rate (Liu and $\mathrm{Wu}, 1997)$. The slope runoff yielding process can be divided into the following three steps: the first step is that rainfall begins infiltration and is completely infiltrated; in the second step, infiltration and runoff are generated at the same time, wherein infiltration and runoff curves have similar linear relations; the third step belongs to a runoff step in which infiltration can be ignored (Sidle et al., 1995; Zhang et al., 2000; Daniel, 1998).

It is incontrovertible that surface and underground loss exists in karst regions, but people always ignore underground water- and soil-loss research and only pay attention to studying surface water and soil loss during the research on water and soil loss in karst regions. The research is comprised of monitoring soil surface erosion state in karst regions through runoff plot (Wu et al., 2005; Chen et al., 2007; Peng et al., 2008; Li et al., 2009), research on surface soil erosion characteristics in different slope positions in karst regions through ${ }^{137} \mathrm{Cs}$ (Fu et al., 2007; X. Zhang et al., 2007; Timothy et al., 1999; Bissonnais et al., 2005), research on soil erosion and the weathering process in small drainage basins using the U-system method (Anthony et al., 2008), research on the influence on soil erosion in karst regions by rainfall intensity through indoor simulation tests (Cai et al., 2009), speculation on the state of soil erosion in Yunnan Stone Forest regions through stalagmite records (Cai et al., 2003), monitoring surface water and soil loss in karst regions through anchored piles, de-silting basins and check dams (Zhang et al., 2003; Peng and Yang, 2001; Long, 2006), and research on surface erosion characteristics in karst regions using the magnetic trace method (Royall, 2001). Dong et al. (2006) calculated water- and soil-loss vector or analyzing waterand soil-loss sensibility in karst regions by directly applying the existing water- and soil-loss models through GIS. Gao et al. (2010) researched different types of soil erosion characteristics in Guizhou by measuring soil antishock coefficients, disintegration coefficients and erodibility and $\mathrm{Li}$ et al. (2007) researched grading standards of water and soil loss in karst regions and presented a series of grading standards suitable for water and soil loss in karst regions according to special lithological characters in karst regions. The above scholars mainly performed research in the aspect of surface waterand soil-loss characteristics, but as karst regions do not only have surface loss, but also have underground soil leakage, the water- and soil-loss characteristics in karst regions can be more accurately reflected only by integrating the analysis and research on surface water and soil loss and underground soil leakage.

In recent years, with the constant depth of research on karst regions, some scholars did theoretical research on surface and underground loss in karst regions in a macroscopic view. Zhou et al. (2009) researched water and soil loss and soil leakage modes in the Puding karst region, generalized the water- and soil-loss and soil-leakage modes in karst regions, discussed the relation among raindrop splash erosion, slope erosion, ponor leakage and underground river migration during the water- and soil-loss process, and theoretically analyzed the action mechanism of water and soil loss in karst regions. Geissenon et al. (1996) macroscopically analyzed surface and underground leakage modes in Mexico, can successfully predict ponor and high-risk regions of karst pipelines by applying classification trees, so that soil erosion risk graphs and water- and soil-conservation plans can also be made according to classification trees given that no expert guidance exists, but surface soil erosion degrees under different types cannot be successfully predicted. Zhang et al. (2009) proposed that karst mountain area soil loss comprises chemical loss, physical loss and biological loss, wherein physical loss comprises surface loss and underground loss. Kheir et al. (2008) evaluated water- and soilloss sensibility states in Mediterranean karst regions through remote sensing (RS) and graphic information system (GIS), assessment indexes comprise landform, soil, land-use type and rainfall erosion indexes, and also comprise rock leakage, including influence on water and soil loss by lithological characters, drainage density and karst landform, Wang et al. (2009) analyzed the underground water- and soil-loss mechanism in karst regions. Chai et al. (1989) obtained the result that the soil-loss tolerance in the Guangxi karst region is $68 \mathrm{t}\left(\mathrm{km}^{2} \times \mathrm{a}\right)^{-1}$ according to the corrosion speed of carbonate rocks in Guangxi, and Z. Zhang et al. (2007) proposed a viewpoint that reasonable erosion amount is required to replace the acceptable erosion for karst regions. The consensus that lithologic character difference causes water and soil loss in karst regions different from water and soil loss in non-karst regions is gradually achieved. Simultaneously soil leakage rates in karst regions are hugely different from each other because of different lithologic character combinations and different pore fissure development levels. For example, Zhang et al. (2007) proposed that the soil leakage can reach $100 \%$ in pure limestone areas, and the soil leakage can also be as low as zero in non-pure limestone areas. The above un- 
Table 1. Soil particle composition.

\begin{tabular}{lrrrrrr}
\hline Soil particle diameter & $\geq 0.25 \mathrm{~mm}$ & $\geq 0.05 \mathrm{~mm}$ & $\leq 0.05 \mathrm{~mm}$ & $\leq 0.01 \mathrm{~mm}$ & $\leq 0.005 \mathrm{~mm}$ & $\leq 0.001 \mathrm{~mm}$ \\
\hline Content & $0.09 \%$ & $9.73 \%$ & $90.27 \%$ & $74.14 \%$ & $63.93 \%$ & $48.55 \%$ \\
\hline
\end{tabular}

derground leakage is mainly researched from a large scale perspective, and few people do research from a micro perspective, so that combining environmental factors and geological factors and analyzing soil leakage mechanism in karst regions from a micro perspective are very important.

In this paper, the influences of pore fissure degrees, bedrock bareness ratios, rainfall intensities and rainfall duration on soil erosion in karst regions were researched by a combination of surface and underground soil erosion under artificial simulation rainfall condition. Results obtained in this paper would provide a theoretical basis for subsequent researching on the relationship between underground and surface water and soil loss in karst regions and, simultaneously, provide a reference for controlling soil erosion and water loss in karst regions.

\section{Materials and methods}

\subsection{Study area}

Soil for testing was collected in a typical karst region $\left(26^{\circ} 28^{\prime} 32^{\prime \prime} \mathrm{N}, 106^{\circ} 42^{\prime} 02^{\prime \prime} \mathrm{E}\right)$ in Huaxi district, Guizhou province in China (Fig. 1). The study area has a subtropical humid monsoon climate with a mean annual temperature of $14.9^{\circ} \mathrm{C}$, annual precipitation of $110 \mathrm{~mm}$, annual frostfree period of 260 days or more and effective accumulated temperature of $4500^{\circ} \mathrm{C}$. The land area of bedrock bared accounted for $23.8 \%$ of total area. The main component of bared bedrock is carbonate rocks with the lowest size of $25 \mathrm{~cm}$.

Soil texture is acarbonatite and devolved calcareous clay loam and soil particle compositions are shown in Table 1.

\subsection{Test equipment}

Test equipment mainly comprises of a rainfall simulator and a steel tank (Fig. 2). The rainfall simulator is a portable fully automatic rain maker with four stainless steel downward sprayers produced by Xi'an Qingyuan Measurement and Control Technology Co., Ltd (Model: QYJY-501). This simulator system was similar to that described by Cerdà (1998a); the height of sprayer was $6 \mathrm{~m}$; the rain intensity can be adjusted from 10 to $200 \mathrm{~mm} \mathrm{~h}^{-1}$; and the effective area of rainfall is $6.5 \mathrm{~m} \times 6.5 \mathrm{~m}$, and the uniformity of raindrops distribution is more than $85 \%$. The length of steel tank is $4 \mathrm{~m}$, the width is $1.5 \mathrm{~m}$ and the depth is $35 \mathrm{~cm}$. Total of 192 drainage holes with a diameter of $5 \mathrm{~cm}$ were uniformly formed at the bottom of tank for free-drainage of infiltrating water. The

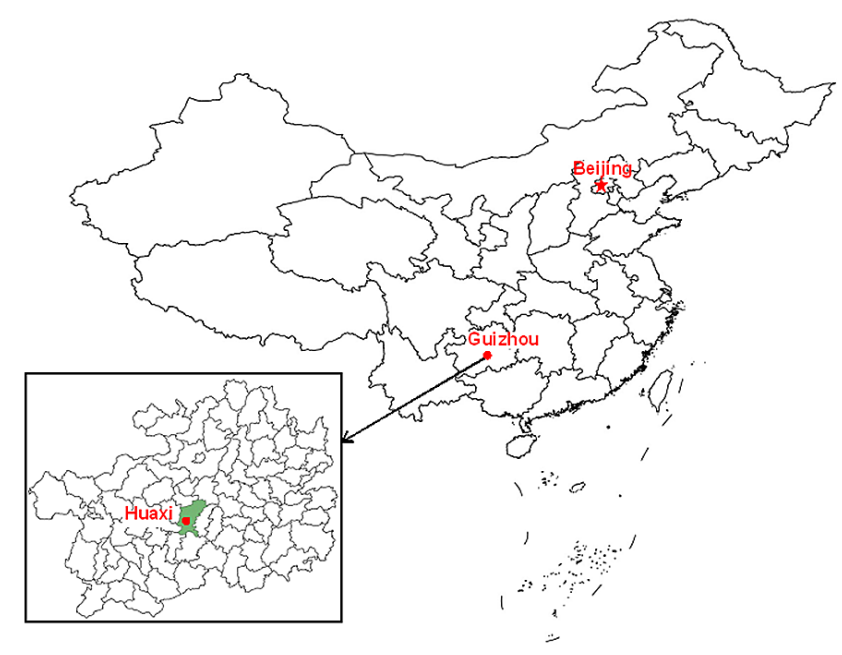

Figure 1. Geographic situation of the study area in China.

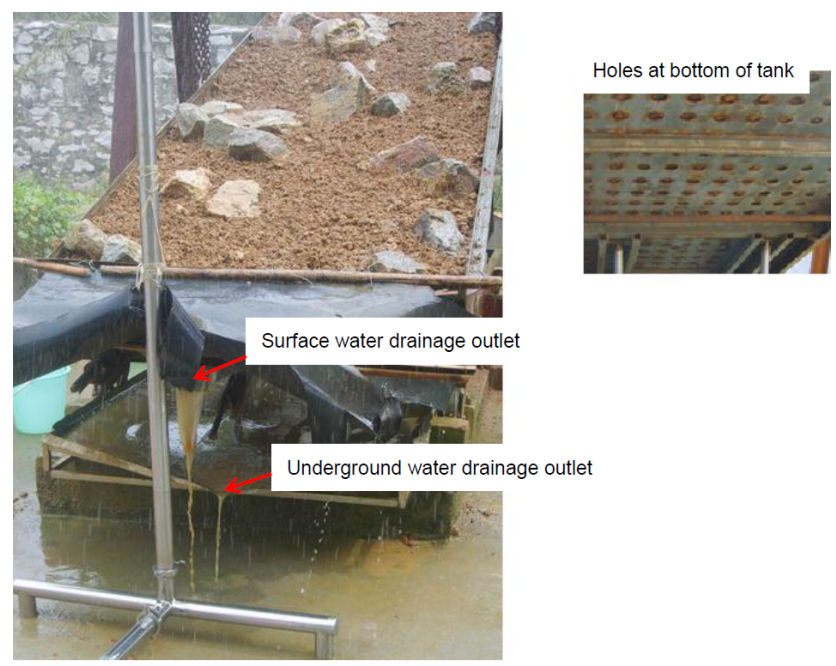

Figure 2. Image of steel tank.

porosity of drainage holes at the bottom of tank can be adjusted from 0 to $6 \%$ to simulate varied pore fissure degrees of underground bedrock. During the experiment, surface runoff and underground runoff from drainage outlets can be collected respectively at the lower end of the steel tank.

\subsection{Test design}

The pore fissure degrees of a tank bottom plate were 1, 2, 3,4 and $5 \%$. The bareness ratios of slope bedrock were 10 , 
$20,30,40$ and $50 \%$. The rainfall intensities were $30,50,80$, 120 and $150 \mathrm{~mm} \mathrm{~h}^{-1}$. The rainfall duration was $90 \mathrm{~min}$ for all rainfall events. A total of nine measurement durations were completed and each duration was $10 \mathrm{~min}$. The soil compactness was 1070,760 and $410 \mathrm{kPa}$ from the lower part to the upper part. This compactness is similar to the actual measurement in field. According to a previous research reported by Tian et al. (2005), the critical slope of the changes of soil erosion intensity is approximately $25^{\circ}$. In this paper, experimental slope is $25^{\circ}$. The test repeated twice.

\subsection{Soil layer simulation}

The procedure to prepare each soil layer was as follows: first carbonate rocks were randomly arranged in the steel tank and the sizes of rocks were random. Secondly, soil was homogenously backfilled in space of rocks in layer-by-layer with hands and rakes to simulate different bareness ratios of slope bedrocks. The total depth of soil layer was $30 \mathrm{~cm}$, which is the average soil layer thickness in the field bared slope characteristic according to investigation results. During soil filling, the soil layer was divided into 3 sub-layers from the lower part to the upper part. For each sub-layer, the thickness of soil was $10 \mathrm{~cm}$, but the amount of soil was not constant. After placing the soil, it was slightly packed with a wooden block in order to obtain needed soil compactness for each sub-layer. A soil compactness measurer was used to measure soil compactness. As procedures described above, we can simulated four bareness ratios of slope bedrocks, i.e., $10,20,30,40$ and $50 \%$.

\subsection{Sample collection}

When rainfall test is begun, the test design begins timing when runoff is produced from the surface and underground, then runoff sediment samples are collected through a small plastic bucket by taking $10 \mathrm{~min}$ as a unit. They are then are transferred into a $65 \mathrm{~L}$ plastic large bucket with scales marked, which is used for calculating the accumulated runoff amount. The water sample is then filled to the middle layer part of the bucket through a water bottle after being blended, the weight of soil in the water bottle is measured, and then the suspended load loss amount can be obtained through the ratio of the water volume in the water bottle to the water volume in the small bucket. Water in the small bucket is then poured out, and the amount of soil deposited at the bottom of the small bucket is the bottom load loss amount.

A statistical analysis of the data was performed through SPSS Statistics 17.0 software.

\section{Results}

\subsection{Analysis on influence on slope runoff and sediment production by rainfall intensity}

The influence on slope runoff and sediment production by rainfall intensity is very obvious, and the relationship between rainfall intensity and slope runoff and sediment production is closed. With the increasing of rainfall intensity, the increasing rate of slope accumulated sediment amount is higher than that of accumulated runoff amount (Zhu et al., 2009). Runoff is increased with the increasing of rainfall intensity, and under identical rainfall intensity, the erosion amount of surface with loose deposits is the greatest, the erosion amount of excavated bare areas takes second place, and the erosion amount of surface with vegetation cover is the lowest (Li and He, 2006; Leh et al., 2013). Soil erosion is obviously increased with the increasing of rainfall intensity. The influence on soil erosion by rainfall intensity is the biggest in the bare slope condition. The influence on soil erosion by slope length and by slope gradient is the approximately the same; the more the slope length is and the steeper the slope surface is, the higher the soil erosion is, and conversely the lower soil erosion is (Wang et al., 2004; Ziadat and Yaimeh, 2013).

For the influence on soil erosion by rainfall intensity, the statistical results refer to Table 2, and the table shows that slop runoff and sediment amounts are increased with the increasing of the rainfall intensity, surface soil is lost in the bottom- and suspended-load modes, and underground soil is lost in a suspended load mode. When the rainfall intensity is low $\left(30 \mathrm{~mm} \mathrm{~h}^{-1}\right)$, underground runoff amount is higher than surface runoff amount. When the rainfall intensity is high $\left(150 \mathrm{~mm} \mathrm{~h}^{-1}\right)$, underground runoff amount is smaller than surface runoff amount. This shows that the variation amplitude of the surface runoff amount is higher than that of underground runoff amount because the soil permeability variation is slight when the underground pore fissure degree is not changed. The rainfall capacity is continuously increased with the increasing of rainfall intensity, except with permeated rainfall amount. The rainfall amount is lost along with surface, and then the variation amplitude of the surface runoff amount is higher. When the rainfall intensity is low ( 30 and $50 \mathrm{~mm} \mathrm{~h}^{-1}$ ), bottom load loss is not produced on the surface, because the surface runoff is small. In this case, the tractive force is small (and only small soil particles are lost with runoff suspension), and only suspended load loss is produced. Only when the rainfall is increased to $80 \mathrm{~mm} \mathrm{~h}^{-1}$ are bottom load and suspended load loss produced on the surface. From the surface soil loss amount, it can be seen that soil is mainly lost in a surface suspended load mode. Secondly, soil is lost in an underground suspended load mode in the second place. Thirdly, soil is lost in a surface bottom load. The increasing rate of accumulated sediment yield is higher than that of accumulated runoff yield according to the 
Table 2. Rainfall intensity on the impact of runoff and sediment production.

\begin{tabular}{lrrrrr}
\hline Rainfall intensity $\left(\mathrm{mm} \mathrm{h}^{-1}\right)$ & 30 & 50 & 80 & 120 & 150 \\
\hline Surface-accumulated runoff amount (L) & 47.3 & 107.0 & 255.5 & 376.5 & 402.0 \\
Underground-accumulated runoff amount (L) & 149.5 & 226.5 & 249.5 & 258.5 & 289.0 \\
Surface-accumulated bottom load amount (g) & 0.00 & 0.00 & 63.44 & 99.36 & 210.05 \\
Surface-accumulated suspended load amount (g) & 81.33 & 214.46 & 459.46 & 528.35 & 1625.87 \\
Underground-accumulated suspended load amount (g) & 121.52 & 126.04 & 217.38 & 219.03 & 578.89 \\
\hline
\end{tabular}

Note: in the table, the pore fissure degree is $2 \%$, the slope gradient is $25^{\circ}$, the rock bareness ratio is $40 \%$, and the rainfall duration is $90 \mathrm{~min}$.

Table 3. Regression equation of accumulated runoff and sediment production and rainfall intensity $(x)$.

\begin{tabular}{llc}
\hline Indexes & Regression equation & $R^{2}$ \\
\hline $\begin{array}{l}\text { Surface-accumulated } \\
\text { runoff amount }\end{array}$ & $y=97.89 x-56.01$ & 0.96 \\
$\begin{array}{l}\text { Surface-accumulated } \\
\text { bottom load }\end{array}$ & $y=13.85 x^{2}-31.14 x+15.67$ & 0.98 \\
$\begin{array}{l}\text { Surface-accumulated } \\
\text { suspended load }\end{array}$ & $y=125.19 x^{2}-410.85 x+437.34$ & 0.92 \\
$\begin{array}{l}\text { Underground-accumulated } \\
\text { runoff amount }\end{array}$ & $y=31.10 x+141.30$ & 0.87 \\
$\begin{array}{l}\text { Underground-accumulated } \\
\text { suspended load }\end{array}$ & $y=44.36 x^{2}-165.37 x+260.76$ & 0.91 \\
\hline
\end{tabular}

increasing rate of accumulated runoff and sediment amounts, and this result is similar with the research result of Zhu et al. (2009).

By taking rainfall intensity as a variable and corresponding accumulated runoff and sediment production as dependent variables to perform regression analysis and multimodel fitting selection, the obtained fitting results refer to Table 3. The table shows that optimally the regression relationship model between rainfall intensity and slope surface and underground runoff and sediment production take a linear quadratic polynomial, except a fitting determination coefficient of underground-accumulated runoff amount. Other fitting determination coefficients are larger than 0.9 and reach significance level. This shows that the relation between slope surface, underground runoff, sediment production and rainfall intensity is close, and the relation is positively correlated. Established models based on multiple simulation rainfall results can be used for predicting the trend of water and soil loss in the southwest karst regions, and can be used for evaluating long-term effects of various measures on karst region governance by being coupled into regional models.

\subsection{Influence on slope runoff and sediment production by underground pore fissure degree}

The statistical results of the influence on slop runoff and sediment production by underground pore fissure degree refer to Table 4 . In the table, rainfall data with different pore fissure degrees in identical conditions (the rock bareness ratio is $30 \%$, the slope gradient is $25^{\circ}$, and the runoff yielding time is $90 \mathrm{~min}$ ) are taken as examples. From Table 4, it can be seen that surface soil is lost in bottom load and suspended load modes, and underground soil is lost in a suspended load mode. When the pore fissures are the same, surface and underground runoff and sediment amounts are increased with the increasing of rainfall intensity, and the variation amplitude of accumulated sediment amount is larger than that of accumulated runoff amount. When the rainfall intensity is smaller $\left(30 \mathrm{~mm} \mathrm{~h}^{-1}\right)$ and the underground pore fissure degree is larger (3, 4 and $5 \%$ ), bottom load loss is produced on the surface, and only suspended load loss is produced because the soil permeability is high when the underground pore fissure degree is large and the rainfall intensity is small, the surface runoff is small, only small soil particles are lost with runoff suspension, and suspended load loss is not produced. When the rainfall intensity is not changed, surface runoff and sediment amounts are reduced with the increasing of the underground pore fissure degree. When the underground runoff and sediment amounts are the opposite and continuously increased (because the underground pore fissure degree is increased), the leakage rate is increased, the surface runoff and sediment yields are reduced, and the underground runoff and sediment yields are increased. When the underground pore fissure is $1 \%$ and the rainfall intensity is $150 \mathrm{~mm} \mathrm{~h}^{-1}$, the total soil erosion intensity is the highest, the total erosion amount reaches $33.2 \mathrm{~g} \mathrm{~min}^{-1}$. When the underground pore fissure is $5 \%$, the total erosion intensity is the lowest.

This study takes underground pore fissure degree as a variable and accumulated runoff and sediment production as dependent variables to perform regression analysis, and the obtained results are shown on Table 5. The table shows that the surface runoff and sediment production and underground pore fissure degree form a negative relationship, while the underground runoff and sediment production and underground fissure degree form a positive relationship. Fitting determination coefficients are larger than 0.8 and reach significance level. This shows that the relation between slop surface and underground sediment production and rainfall intensity is close. Established models based on multiple simulation rainfall results can be used for predicting the trend of karst water and soil loss in the southwest region, and can be used for evaluating long-term effects of various measures 
Table 4. Degrees of holes and fissures on the impact of runoff and sediment production.

\begin{tabular}{|c|c|c|c|c|c|c|}
\hline \multirow{2}{*}{$\begin{array}{l}\text { Underground pore } \\
\text { fissure degree }\end{array}$} & \multirow[t]{2}{*}{ Indexes } & \multicolumn{5}{|c|}{ Rainfall intensity $\left(\mathrm{mm} \mathrm{h}^{-1}\right)$} \\
\hline & & 30 & 50 & 80 & 120 & 150 \\
\hline \multirow[t]{5}{*}{$1 \%$} & Underground-accumulated runoff amount (L) & 68.1 & 97.0 & 112.0 & 126.5 & 139.5 \\
\hline & Surface-accumulated runoff amount (L) & 188.5 & 285.0 & 523.0 & 705.5 & 758.5 \\
\hline & Underground-accumulated suspended load amount (g) & 31.30 & 45.18 & 102.70 & 136.30 & 155.30 \\
\hline & Surface-accumulated bottom load amount (g) & 7.23 & 26.82 & 675.34 & 933.25 & 1033.00 \\
\hline & Surface-accumulated suspended load amount (g) & 206.98 & 295.02 & 1699.44 & 1769.30 & 1799.00 \\
\hline \multirow[t]{5}{*}{$2 \%$} & Underground-accumulated runoff amount $(\mathrm{L})$ & 80.5 & 112.0 & 131.5 & 205.0 & 222.0 \\
\hline & Surface-accumulated runoff amount (L) & 149.5 & 247.5 & 509.0 & 587.0 & 685.0 \\
\hline & Underground-accumulated suspended load amount (g) & 32.42 & 50.59 & 107.56 & 141.32 & 191.50 \\
\hline & Surface-accumulated bottom load amount $(\mathrm{g})$ & 3.11 & 22.04 & 446.44 & 557.10 & 627.80 \\
\hline & Surface-accumulated suspended load amount (g) & 178.60 & 265.00 & 1440.15 & 1531.60 & 1640.00 \\
\hline \multirow{5}{*}{$3 \%$} & Underground-accumulated runoff amount (L) & 95.0 & 126.5 & 215.5 & 255.0 & 277.0 \\
\hline & Surface-accumulated runoff amount (L) & 143.5 & 222.5 & 401.0 & 585.5 & 629.5 \\
\hline & Underground-accumulated suspended load amount (g) & 33.94 & 92.95 & 578.89 & 583.97 & 632.20 \\
\hline & Surface-accumulated bottom load amount (g) & 0.00 & 18.99 & 393.30 & 507.80 & 596.10 \\
\hline & Surface-accumulated suspended load amount (g) & 107.00 & 214.46 & 1125.87 & 1377.90 & 1425.00 \\
\hline \multirow[t]{5}{*}{$4 \%$} & Underground-accumulated runoff amount (L) & 98.0 & 126.5 & 272.0 & 280.5 & 293.0 \\
\hline & Surface-accumulated runoff amount (L) & 118.5 & 206.5 & 379.0 & 509.0 & 598.0 \\
\hline & Underground-accumulated suspended load amount (g) & 62.51 & 101.39 & 592.22 & 635.75 & 678.90 \\
\hline & Surface-accumulated bottom load amount (g) & 0.00 & 17.66 & 393.24 & 447.00 & 486.50 \\
\hline & Surface-accumulated suspended load amount (g) & 97.00 & 138.52 & 991.17 & 1011.20 & 1190.60 \\
\hline \multirow[t]{5}{*}{$5 \%$} & Underground-accumulated runoff amount (L) & 119.5 & 253.5 & 295.0 & 302.5 & 345.2 \\
\hline & Surface-accumulated runoff amount (L) & 98.0 & 132.5 & 340.5 & 481.2 & 544.0 \\
\hline & Underground-accumulated suspended load amount (g) & 67.36 & 109.36 & 618.89 & 670.80 & 698.90 \\
\hline & Surface-accumulated bottom load amount (g) & 0.00 & 5.07 & 316.15 & 368.50 & 426.50 \\
\hline & Surface-accumulated suspended load amount (g) & 88.00 & 115.35 & 158.22 & 160.50 & 730.60 \\
\hline
\end{tabular}

Note: rock bareness ratio is $30 \%$, the slop gradient is $25^{\circ}$ and the rainfall duration is $90 \mathrm{~min}$.

Table 5. Regression equation of accumulated runoff and sediment production and underground pore fissure degree $(x)$.

\begin{tabular}{llc}
\hline Indexes & Regression equation & $R^{2}$ \\
\hline $\begin{array}{l}\text { Surface-accumulated } \\
\text { runoff amount }\end{array}$ & $y=-52.66 x+731.62$ & 0.91 \\
$\begin{array}{l}\text { Surface-accumulated } \\
\text { bottom load }\end{array}$ & $y=-123.96 x+934.61$ & 0.80 \\
$\begin{array}{l}\text { Surface-accumulated } \\
\text { suspended load }\end{array}$ & $y=-373.80 x+2291.50$ & 0.89 \\
$\begin{array}{l}\text { Underground-accumulated } \\
\text { runoff amount }\end{array}$ & $y=42.75 x+105.65$ & 0.93 \\
$\begin{array}{l}\text { Underground-accumulated } \\
\text { suspended load }\end{array}$ & $y=156.34 x-35.40$ & 0.83 \\
\hline
\end{tabular}

Note: the results in the table are obtained by taking rainfall data being $120 \mathrm{~mm} \mathrm{~h}^{-1}$ as an example.

on karst regional governance by being coupled into regional models.

\subsection{Influence on slope runoff and sediment production on rainfall duration}

Surface and underground runoff and sediment production present a different change rules along with rainfall duration (Table 6). In the table, the pore fissure is $3 \%$, the rock bareness ratio is $30 \%$, the slope gradient is $25^{\circ}$ and the rainfall intensity is $50 \mathrm{~mm} \mathrm{~h}^{-1}$. From the table, it can be seen that soil is mainly lost in a surface suspended load mode, the surface suspended load loss is about $2 / 3$ of the total soil loss amount, and ground suspended loss takes second place. When raindrops hit the surface, a crust forms during rainfall. The formation of crusts increases surface runoff erosion and reduces soil infiltration rate. This formation also increases surface-runoff-erosion-damaged crust and increased soil seepage rate. Raindrops continued to hit the surface, leading the formation of crust. Soil permeability showed volatility which was from reduction to increases, reduction, and so on. Surface and subsurface runoff were volatile with 
Table 6. Relationship between the accumulation of runoff and sediment production and rainfall duration.

\begin{tabular}{lrrrrr}
\hline $\begin{array}{l}\text { Runoff } \\
\text { yielding } \\
\text { time (min) }\end{array}$ & $\begin{array}{r}\text { Surface } \\
\text { runoff } \\
(\mathrm{L})\end{array}$ & $\begin{array}{r}\text { Underground } \\
\text { runoff } \\
(\mathrm{L})\end{array}$ & $\begin{array}{r}\text { Surface } \\
\text { bottom } \\
\text { load }(\mathrm{g})\end{array}$ & $\begin{array}{r}\text { Surface } \\
\text { suspended } \\
\text { load }(\mathrm{g})\end{array}$ & $\begin{array}{r}\text { Underground } \\
\text { suspended } \\
\text { load }(\mathrm{g})\end{array}$ \\
\hline $0-10$ & 25.0 & 13.5 & 5.28 & 30.08 & 10.55 \\
$10-20$ & 21.0 & 12.0 & 2.51 & 23.98 & 9.66 \\
$20-30$ & 22.0 & 14.5 & 1.24 & 21.65 & 11.59 \\
$30-40$ & 23.0 & 13.0 & 0.98 & 21.91 & 8.70 \\
$40-50$ & 25.0 & 13.5 & 2.82 & 23.73 & 9.18 \\
$50-60$ & 27.0 & 14.0 & 1.79 & 23.92 & 11.09 \\
$60-70$ & 27.0 & 15.5 & 1.35 & 26.22 & 13.50 \\
$70-80$ & 27.0 & 16.0 & 1.99 & 23.38 & 9.58 \\
$80-90$ & 25.5 & 14.5 & 1.03 & 19.61 & 9.11 \\
\hline Total & 222.5 & 126.5 & 18.99 & 214.46 & 92.95 \\
Average & 24.7 & 14.1 & 2.11 & 23.83 & 10.33 \\
\hline
\end{tabular}

Note: the pore fissure is $3 \%$, the rock bareness ratio is $30 \%$, the slope gradient is $25^{\circ}$ and the rainfall intensity is $50 \mathrm{~mm} \mathrm{~h}^{-1}$.

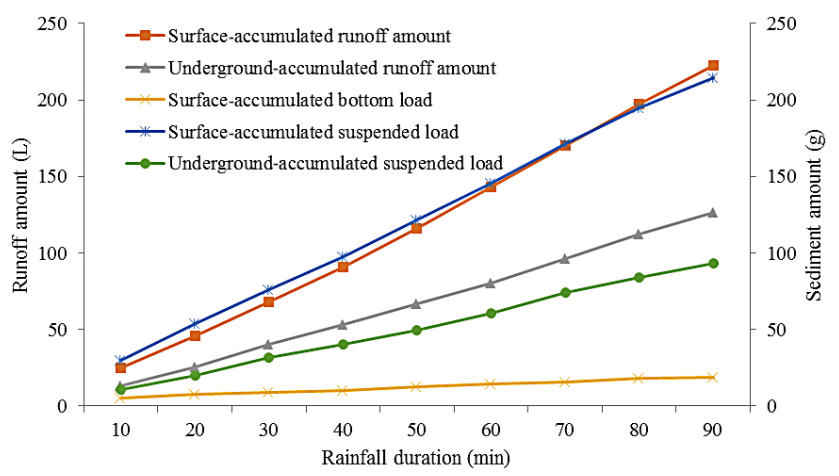

Figure 3. Change of accumulation runoff and sediment with increasing rainfall time (experiment conditions: rainfall intensity is $50 \mathrm{~mm} \mathrm{~h}^{-1}$; degree of pore fissure is $30 \%$; bedrock rate is $3 \%$; slope steepness is $25^{\circ}$ ).

rainfall duration, and the result is similar with the research result of Chen et al. (2011).

Figure 3 shows the relationship of rainfall duration and all accumulated amounts. From the figure it can be seen that surface- and underground-accumulated runoff, sedimentyielding amounts and rainfall duration form a negative relationship, the bottom load produced on the surface is smallest, the variation amplitude is the smallest and nearly a horizontal line, and the slope $k=1.7314$. The variation amplitude of surface-accumulated runoff amount is the largest, and the slope is $k=25.183$. The regression relation model fitting results of surface and underground runoff and sediment production and rainfall duration refer to Table 7 .

\subsection{Influence on slope runoff and sediment production by rock bareness ratio}

Stony desertification classification is determined according to rock bareness intensity, the rock bareness ratio of severe stony desertification regions is larger than $80 \%$, the rock
Table 7. Regression equation of accumulated runoff and sediment production and rainfall duration $(x)$.

\begin{tabular}{lcc}
\hline Indexes & Regression equation & $R^{2}$ \\
\hline $\begin{array}{l}\text { Surface-accumulated } \\
\text { runoff amount }\end{array}$ & $y=25.18 x-30.93$ & 0.99 \\
$\begin{array}{l}\text { Surface-accumulated } \\
\text { bottom load }\end{array}$ & $y=1.73 x+2.11$ & 0.99 \\
$\begin{array}{l}\text { Surface-accumulated } \\
\text { suspended load }\end{array}$ & $y=23.32 x-17.15$ & 0.99 \\
$\begin{array}{l}\text { Underground-accumulated } \\
\text { runoff amount }\end{array}$ & $y=14.18 x-16.93$ & 0.99 \\
$\begin{array}{l}\text { Underground-accumulated } \\
\text { suspended load }\end{array}$ & $y=10.43 x-10.94$ & 0.99 \\
\hline
\end{tabular}

bareness ratio of moderate stony desertification regions is larger than $70 \%$, and when the rock bareness ratio of mild stony desertification regions is larger than $60 \%$ (Hu et al., 2008), soil cover in the mild stony desertification regions is basically continuous, and the regions belong to arable exploitable regions. In this paper, the highest researched rock-bareness ratio is $50 \%$, and the region belongs within the scope of arable exploitable region, and does not belong within the scope of mild stony desertification.

In this paper, for the influence on slop runoff and sediment production by rock bareness ratio, the pore fissure is $3 \%$, the slope gradient is $25^{\circ}$ and the rainfall intensity is $90 \mathrm{~mm} \mathrm{~h}^{-1}$, and the statistical results refer to Table 7. From the table it can be seen that when the rainfall intensity is low $\left(30 \mathrm{~mm} \mathrm{~h}^{-1}\right)$, no bottom load loss is produced on the surface, and only suspended load loss is produced. When the rock bareness ratio is $50 \%$ and the rainfall intensity is 30 and $50 \mathrm{~mm} \mathrm{~h}^{-1}$, no runoff is produced on the surface, so that only underground water and soil loss is produced on the surface. With the increasing of the bedrock bareness ratio, the surface allowable infiltration area is reduced, the impermeable area is increased, and the effect on preventing rainfall leakage by bared bedrock is increased, so that the soil and water infiltration loss amount is reduced, but the soft and hard contact surface between soil and rock and the intercept effect on rainfall by surface are increased relatively, and the water and soil infiltration rate is increased on the contrary, so that the soil leakage loss depends on the bedrock bareness ratio and the soft and hard contact surface between soil and rock. When the rainfall intensity is $150 \mathrm{~mm} \mathrm{~h}^{-1}$ and the rock bareness ratio is $10 \%$, allowed infiltration of surface area is larger, impervious area is smaller and the soil infiltration rate is larger. When the rock bareness ratio is increased from 10 to $20 \%$, allowed infiltration of surface area reduced, impervious area increased, so the soil infiltration rate decreases. When the rock bareness ratio is increased from 20 to $30 \%$, allowed infiltration of surface area increased, impervious area reduced, but the soft and hard contact surface between soil and rock and the intercept effect on rainfall by surface are increased 
Table 8. Rates of exposed bedrock on the impact of runoff and sediment production.

\begin{tabular}{|c|c|c|c|c|c|c|}
\hline \multirow[t]{2}{*}{ Rock bareness ratio } & \multirow[t]{2}{*}{ Indexes } & \multicolumn{5}{|c|}{ Rainfall intensity $\mathrm{mm} \mathrm{h}^{-1}$} \\
\hline & & 30 & 50 & 80 & 120 & 150 \\
\hline \multirow[t]{5}{*}{$10 \%$} & Underground-accumulated runoff amount (L) & 59.5 & 138.0 & 240.0 & 277.5 & 393.5 \\
\hline & Surface-accumulated runoff amount (L) & 82.5 & 193.5 & 385.5 & 405.5 & 502.0 \\
\hline & Underground-accumulated suspended load amount (g) & 79.03 & 104.54 & 141.51 & 268.91 & 627.39 \\
\hline & Surface-accumulated bottom load amount (g) & 0.00 & 28.69 & 89.10 & 261.50 & 611.50 \\
\hline & Surface-accumulated suspended load amount (g) & 309.21 & 408.29 & 800.39 & 1429.20 & 2418.00 \\
\hline \multirow[t]{5}{*}{$20 \%$} & Underground-accumulated runoff amount (L) & 87.5 & 105.0 & 177.5 & 323.0 & 385.5 \\
\hline & Surface-accumulated runoff amount (L) & 122.0 & 227.5 & 400.0 & 514.5 & 669.0 \\
\hline & Underground-accumulated suspended load amount (g) & 112.90 & 183.23 & 202.41 & 426.00 & 502.63 \\
\hline & Surface-accumulated bottom load amount (g) & 0.00 & 145.60 & 358.60 & 465.20 & 771.05 \\
\hline & Surface-accumulated suspended load amount (g) & 107.00 & 381.70 & 751.90 & 1015.80 & 1369.40 \\
\hline \multirow[t]{5}{*}{$30 \%$} & Underground-accumulated runoff amount (L) & 119.5 & 206.5 & 295.0 & 370.5 & 395.0 \\
\hline & Surface-accumulated runoff amount (L) & 146.5 & 222.5 & 401.0 & 587.0 & 685.0 \\
\hline & Underground-accumulated suspended load amount (g) & 126.04 & 215.75 & 578.89 & 625.10 & 678.89 \\
\hline & Surface-accumulated bottom load amount (g) & 0.00 & 138.99 & 393.24 & 956.60 & 1531.70 \\
\hline & Surface-accumulated suspended load amount (g) & 220.00 & 415.35 & 814.46 & 1177.90 & 1625.90 \\
\hline \multirow[t]{5}{*}{$40 \%$} & Underground-accumulated runoff amount (L) & 256.0 & 308.5 & 406.5 & 414.5 & 424.5 \\
\hline & Surface-accumulated runoff amount (L) & 32.0 & 89.5 & 222.5 & 249.5 & 362.5 \\
\hline & Underground-accumulated suspended load amount (g) & 182.82 & 184.33 & 502.63 & 572.80 & 621.80 \\
\hline & Surface-accumulated bottom load amount (g) & 0.00 & 18.96 & 60.78 & 507.80 & 627.80 \\
\hline & Surface-accumulated suspended load amount (g) & 52.00 & 72.16 & 219.82 & 252.34 & 387.17 \\
\hline \multirow[t]{5}{*}{$50 \%$} & Underground-accumulated runoff amount (L) & 210.5 & 237.5 & 289.5 & 333.5 & 513.5 \\
\hline & Surface-accumulated runoff amount (L) & 0.0 & 0.0 & 294.0 & 431.0 & 466.0 \\
\hline & Underground-accumulated suspended load amount (g) & 118.69 & 202.49 & 399.51 & 415.90 & 489.50 \\
\hline & Surface-accumulated bottom load amount (g) & 0.00 & 0.00 & 51.85 & 60.55 & 60.78 \\
\hline & Surface-accumulated suspended load amount (g) & 0.00 & 0.00 & 554.93 & 602.69 & 1434.90 \\
\hline
\end{tabular}

Note: the pore fissure degree is $3 \%$, the slope degree is $25^{\circ}$ and the rainfall duration is $90 \mathrm{~min}$.

relatively, and the water and soil infiltration rate is increased on the contrary, so that the slope runoff and sediment production present a fluctuating change with the increasing of the rock bareness ratio given that the rainfall intensity is not changed, while the slope runoff and sediment production is increased with the increasing of the rainfall intensity given that the rock bareness ratio is not changed.

By taking rock bareness ratio as a variable and accumulated runoff and sediment production as a dependent variable to perform regression analysis and multi-model fitting selection, the obtained fitting results refer to Table 8. From the table it can be seen that optimally, the regression relationship model between the rock bareness ratio, slope runoff and sediment production takes a quadratic polynomial and a cubic polynomial, except fitting the determination coefficient of the underground accumulated suspended load. Other fitting determination coefficients are larger than 0.9 and do not reach significance level. This does not show that the slope runoff and sediment production are increased or reduced, but rather presents a fluctuating change with the rock bareness ratio increasing. Established models based on multiple sim- ulation rainfall results can be used for predicting the trend of karst water and soil loss in the southwest region, and can be used for evaluating long-term effects of various measures on karst regional governance by being coupled into regional models.

By performing total comparison on fitting determination coefficient $R^{2}$ of all variables and dependent variables, the obtained correlation degree of all factors and soil erosion is as follows: rainfall intensity $>$ rainfall duration $>$ pore fissure degree $>$ bedrock bareness ratio (Table 9 ).

\section{Discussions and prospects}

The correlation degree of soil erosion and all factors is as follows: rainfall intensity $>$ rainfall duration $>$ underground pore fissure degree $>$ bedrock bareness ratio. The slope runoff and sediment production is increased with the increasing of rainfall intensity. The surface soil is lost in bottom- and suspended-load modes, and the underground soil is lost in a suspended load mode. The variation amplitude of surface runoff amount is larger than that of underground runoff 
Table 9. Regression equation of accumulated runoff and sediment production and rock bareness ratio $(x)$.

\begin{tabular}{llc}
\hline Indexes & Regression equation & $R^{2}$ \\
\hline Surface-accumulated runoff amount & $y=46.29 x^{3}-435.55 x^{2}+1184.7 x-408.50$ & 0.63 \\
Surface-accumulated bottom load & $y_{2}=-160.15 x^{2}+924.97 x-562.93$ & 0.83 \\
Surface-accumulated suspended load & $y=58.37 x^{3}-493.88 x^{2} 947.32 x+859.83$ & 0.74 \\
Underground-accumulated runoff amount & $y_{2}=-18.32 x^{2}+130.28 x+154.50$ & 0.83 \\
Underground-accumulated suspended load & $y_{2}=-62.81 x^{2}+420.95 x-110.18$ & 0.94 \\
\hline
\end{tabular}

Note: the results in the table are obtained by taking rainfall data being $120 \mathrm{~mm} \mathrm{~h}^{-1}$ as an example.

amount. When the rainfall is small $\left(30,50 \mathrm{~mm} \mathrm{~h}^{-1}\right)$, no bottom load loss is produced on the surface, and only suspended load loss is produced. Only when the rainfall intensity is increased to $80 \mathrm{~mm} \mathrm{~h}^{-1}$ are bottom load and suspended load loss produced on the surface, and the increasing rate of accumulated sediment runoff amount is higher than that of accumulated runoff amount.

When the underground pore fissure is not changed, the surface and underground runoff as well as sediment production is increased with the increasing of rainfall intensity, and the variation amplitude of the accumulated sediment amount is larger than that of the accumulated runoff amount. When the rainfall is small $\left(30 \mathrm{~mm} \mathrm{~h}^{-1}\right)$ and the underground pore fissure is large (3, 4 and 5\%), bottom load loss produced on the surface is 0 . When the rainfall intensity is not changed, the surface runoff and sediment production is continuously reduced with the increasing of underground pore fissure degree, while the underground runoff and sediment production is contrary and presents a trend of continuously increasing.

Soil is mainly lost in a surface suspended load mode, the surface suspended load loss is about $2 / 3$ of the total soil loss amount, and ground suspended loss takes the second plate; Raindrops hit the surface, forming a crust with rainfall duration. The formation of crusts increases surface runoff erosion and reduces soil infiltration rate. This formation also increases of surface-runoff-erosion-damaged crust and increased soil seepage rate. Raindrops continued to hit the surface, leading the formation of crust. Soil permeability showed volatility which was from reduction to increases, reduction, and so on. Surface and subsurface runoff were volatile with rainfall duration.

When the rainfall intensity is low $\left(30 \mathrm{~mm} \mathrm{~h}^{-1}\right)$, no bottom load loss is produced on the surface, and only suspended load loss is produced. When the rock bareness ratio is $50 \%$, and the rainfall intensity is 30 and $50 \mathrm{~mm} \mathrm{~h}^{-1}$, no runoff is produced on the surface, and only underground water and soil loss are produced. When the rainfall intensity is not changed, the slop runoff and sediment product present a fluctuating change with the increasing of the rock bareness ratio, and when the rock bareness ratio is not changed, the slope runoff and sediment product is increased with the increasing of rainfall intensity. Soil infiltration loss depends on the bedrock bareness ratio and the soft and the hard contact surface be- tween soil and rock. Our results also essentially confirmed the report of Martínez-Zavala and Jordán (2008) and Jiménez et al. (2013). On the whole, our results show further that rock fragments on the soil surface play an important role in controlling soil and water loss in the karst areas (Cerda, 1998b).

A large amount of runoff plot monitoring results show that the surface soil erosion modulus of karst regions is very small, only ranging between 10 tons and several hundreds of tons, and there is a big difference between the surface soil erosion modulus and the result predicted through a corrected universal soil loss equation. Traditional principles of runoff yield under saturated storage and runoff yield under excess infiltration can not perfectly describe the slop runoff and sediment production in karst regions because of the pervasive development of special lithological fissures, ponors and underground rivers in karst regions. After rainfall runoff passes through rock-soil fissures, downward preferential flow is produced. Only by establishing a surface rainfall erosion force model based on the preferential flow principle is it likely that surface soil loss in karst regions can be reasonably predicted.

Developing surface and underground two-layer karst structure causes the coexistence of surface soil loss and underground soil loss because of the special lithology in karst regions. Only by establishing a soil surface and underground loss coupling model can a correct basis be provided for effectively governing water and soil loss in karst regions. Detecting the soil loss in karst regions by adopting a rare earth element trace method in combination with a remote sensing technology is the research direction. This is the most important thing we need to do, so as to establish a water and soil surface and underground loss coupling mode in karst regions. Then a correct basis can be provided for effectively governing water and soil loss in karst regions. 
Acknowledgements. This study is funded by the National Natural Science Foundation of China (41461057; 41061029), Great Special Foundation of Guizhou Province (in the year of 2014, No. 2002) and Projects in the National Science \& Technology Pillar Program during the Twelfth Five-year Plan Period (2011BAC02B02). Thanks go to professor of Ni Jiupai, Zhou Chuan, Zhang Yang, Shi Yonglian, Liang Zengfang, and Liu Yuejiao for providing help.

Edited by: A. Jordán

\section{References}

Anthony, D., Bernard, B., and Turner, S. P.: Uranium-series isotopes in river materials: insights into the timescales of erosion and sediment transport, Earth Planet. Sc. Lett., 265, 1-17, 2008.

Bissonnais, Y. L., Cerdan, O., Lecomte, V., Broard, M., and Peter H. K.: Variability of soil surface characteristics influencing runoff and interrill erosion, Catena, 62, 111-124, 2005.

Biro, K., Pradhan, B., Buchroithner, M., Makeschin, F.: Land use/land cover change analysis and its impact on soil properties in the Northern part of Gadarif region, Sudan, Land Degrad. Dev., 24, 90-102, doi:10.1002/ldr.1116, 2013.

Cai, B., Cheng, H., Hou, J., and Mendel, L.: The Impact of Soil Erosion on The Formation of Yunnan Stone Forest: evidences from Stalagmite and Field Observations, Quat. Sciences, 25, 170-175, 2005.

Cai, X., W, J., Lei, L., Wang, H., and Li, X.: Laboratorial simulation of different rainfall intensity influence on soil erosion in Southwest Karst area, China, J. Soil Water Conserv., 23, 5-13, 2009.

Cerdà, A.: The influence of aspect and vegetation on seasonal changes in erosion under rainfall simulation on a clay soil in Spain, Canadian J. Soil Sci., 78, 321-330, 1998a.

Cerdà, A.: Relationships between climate and soil hydrological and erosional characteristics along climatic gradients in Mediterranean limestone areas, Geomorphology, 25, 123-134, 1998b.

Cerdà, A.: Aggregate stability against water forces under different climates on agriculture land and scrubland in southern Bolivia, Soil Till. Res., 36, 1-8, 2000.

Cerdà, A, Flanagan, D. C., and le Bissonnais, Y.: Soil Erosion and Agriculture, Soil Till. Res., 98-107, doi:10.1016/j.still.2009.10.006, 2009a.

Cerdà, A., Giménez-Morera, A., y Bodí, M. B.: Soil and water losses from new citrus orchards growing on sloped soils in the western Mediterranean basin, Earth Surf. Proc. Land., 34, 18221830, doi:10.1002/esp.1889, 2009b.

Cerdà, A., Hooke, J., and Romero-Diaz, A.: Soil erosion on mediterraneantype-ecosystems, Land Degrad. Dev., 21, 71-74, doi:10.1002/ldr.968, 2010.

Chai, Z.: Study on soil erosion in Guangxi Karst region, J. Mt. Sci.,7, 255-259, 1989.

Chen, Q., Chang, E., Bi, B., Chen, W. T., and Li, D. J.: Comparison between two lands of water and soil conservation in Southeastern Yunnan, Research of Soil and Water Conservation, 14, 281-284, 2007.

Chen, Z., Xia, Q., Shi, D., Liu, H. Y., and Wu, S. F.: Soil surface crust characteristic and response feature to slope erosion base on simulation rainfall, J. Soil Water Conserv., 25, 6-11, 2011.
Daniel, H.: Environmental Soil Physics, Academic Press, 188-190, 1998.

Dong, Y.: Slope Soil Erosion Intensity Spatial Characteristics and Soil Erosion Process Based on Magnetic Measurement, Shandong Agricultural University, 2006.

Fu, W., Zhang, Z., Zhang, H., Zhang, K., and Gu, D. C.: Study on characteristics of soil erosion on Karst hillslope, J. Soil Water Conserv., 21, 38-41, 2007.

Gao, H., Sun, Q., and Yuan, Y.: Characteristics of soil erosion for different land types in Karst areas, B. Soil Water Conservation, 30, 92-96, 2010.

García-Orenes, F., Cerdà, A., Mataix-Solera, J., Guerrero, C., Bodí, M. B., Arcenegui, V., Zornoza, R., and Sempere, J. G.: Effects of agricultural management on surface soil properties and soil-water losses in eastern Spain, Soil Till. Res., 106, 117-123, doi:10.1016/j.still.2009.06.002, 2009.

Gillieson, D., Wallbrink, P., and Cochrranea, A.: Vegetation change, erosion risk and land management on the Nullarbor Plain, Australia, Environ. Geol., 28, 145-153, 1996.

Giménez Morera, A., Ruiz Sinoga, J. D., and y Cerdà, A.: The impact of cotton geotextiles on soil and water losses in Mediterranean rainfed agricultural land, Land Degrad. Dev., 43, 210217, doi:10.1002/ldr.971, 2010.

Haile, G. W. and Fetene, M.: Assessment of soil erosion hazard in Kilie catchment, East Shoa, Ethiopia, Land Degrad. Dev., 23, 293-306, doi:10.1002/ldr.1082, 2012.

Haregeweyn, N., Poesen, J., Verstraeten, G., Govers, G., de Vente, J., Nyssen, J., Deckers, J., and Moeyersons, J.: Assessing the performance of a spatially distributed soil erosion and sediment delivery model (WATEM/SEDEM) in Northern Ethiopia, Land Degrad. Dev., 24, 188-204, doi:10.1002/ldr.1121, 2013.

Hu, Y., Liu, Y., Wu, P., Zhao, X. N., and Niu, W. Q.: Rocky desertification in Guangxi karst mountainous area: its tendency, formation causes and rehabilitation, J. Chinese Agricult. Eng., 24, 96-100, 2008.

Jiménez, M. N., Fernández-Ondoño, E., Ripoll, M. Á, and Bertson, M. N.: Stones and organic mulches improve the Quercus ilex L. afforestation success under Mediterranean climatic conditions, Land Degrad. Dev., 24, 45-54, 2013.

Kheir, R. B., Abdallah, C., and Khawlie, M.: Assessing soil erosion in Mediterranean karst landscapes of Lebanon using remote sensing and GIS, Eng. Geol., 16, 239-254, 2008.

Leh, M., Bajwa, S., and Chaubey, I.: Impact of land use change on erosion risk: and integrated remote sensing geopraphic information system and modeling methodology, Land Degrad. Dev., 24, 409-421, doi:10.1002/ldr.1137, 2013.

$\mathrm{Li}, \mathrm{J}$. and He, Z.: Research on red oil slop runoff and soil erosion under different rainfall intensities, Environment, S1, 10-11, 2006.

Li, S., Ren, H., Yao, X., Zhang, D. Y., and Dai, Q. H.: Study on characteristics of runoff and nutrition loss between different vegetation land in typical karst rock desertification zone, J. Soil Water Conserv., 23, 1-6, 2009.

Li, Y., Shao, J., Wang, S., Wang, J. X., and Li, X. J.: Assessment of soil erosion sensitivity based on the characteristics of karst ecosystem, J. Mt. Sci., 25, 671-677, 2007.

Liu, B. and Wu, F.: Soil Erosion, Shaanxi People's Publishing House, Xi'an, China, 1997.

Long, M.: Water, soil conservation effect and soil erosion models during the ecosystem rehabilitation of karst valleys - taking Hua- 
jiang demonstration area as an example, Chinese Academic Journal (CD) Electronic Journals, 1-120, 2006.

Mandal, D. and Sharda, V. N.: Appraisal of soil erosion risk in the Eastern Himalayan region of India for soil conservation planning, Land Degrad. Dev., 24, 430-437, doi:10.1002/ldr.1139, 2013.

Martínez-Zavala, L. and Jordán, A.: Effect of rock fragment cover on interrill soil erosion from bare soils in Western Andalusia, Spain, Soil Use Manage., 24, 108-117, 2008.

Peng, J. and Yang, M.: On the present soil erosion situation of Huajiang karst gorge in Guizhou province, J. Mt. Sci., 19, 511-515, 2001.

Peng, T., Wang, S., Zhang, X., Zhao, Q. G., and Chen, T. F.: Results of preliminary monitoring of surface runoff coefficients for karst slopes, Earth and Environment, 36, 125-129, 2008.

Prokop, P. and Poręba, G. J.: Soil erosion associated with an upland farming system under population pressure in Northeast India, Land Degrad. Dev., 23, 310-321, doi:10.1002/ldr.2147, 2012.

Royall, D.: Use of mineral magnetic measurements to investigate soil erosion and sediment delivery in a small agricultural catchment in limestone terrain, Catena, 46, 15-34, 2001.

Sidle, R. C., Kitahara, H., and Temjima, T.: Experimental studies on the effcets of pipe flow on through flow partitioning, J. Hydrol., 16, 207-219, 1995.

Sweeting, M. M.: Reflections on the development of Karst geomorphology in Europe and a comparison with its development in China, Z. Geomorphol., 37, 127-138, 1993.

Tian , F., Wang, Z., Niu, Z., Ma, J., and Wu, H.: Experimental research on soil erosion process in Loess hill slope, Agricultural Research in the Arid Areas, 23, 141-146, 2005.

Timothy, A. Q., Gerarel, G., Jean, P., Jeroshuer, H., and Peter, K.: Fine earth translocatio by tillage in stony soils in the Guadalentin southeast Spain, aninvestigation using Caesium-137, Soil Till. Res., 51, 279-301, 1999.

Wang, H., Xiong, K., and Liu, Y.: Mechanism research of soil and water loss underground in karst region, Soil and Water Conservation in China, 8, 11-15, 2009.
Wang, Z., Wang, Y., Huang, X., Wan, X. H., and Liu, Q. S.: Soil erosion process research of the loess bare slope, Research of Soil and Water Conservation, 11, 84-87, 2004.

Wu, S., Zhu, W., Su, W., Liu, T. H., and Li, X. H.: Study on soil erosion and nutrient loss positioning in karst regions, Garsologica Sinica, 24, 302-502, 2005.

Zhang, H., Wang, Y., Bei, Y., Cheng, Y., Shi, Y., Sheng, Q., Yang, M., and Chang, D.: A study on pipe flow on the slope of granite region of the Three Gorges Area of Yangtze River, Journal of Beijing Forestry University, 22, 53-57, 2000.

Zhang, X., Jiao, J., He, X., Wu, S. F., and Li, J.: Soil loss tolerance and reasonable soil loss, Sci. Soil Water Conservation, 5, 114116, 2007.

Zhang, X., Wang, S., and Cao, J.: Mass balance of silicate minerals in soils and soil losses in the karst mountainous regions of Southwest China, Earth and Environment, 37, 97-102, 2009.

Zhang, Y., Xiong, K., An, Y., Liang, H. T., and Wu, K. M.: Soil erosion of Huajiang demonstrating area in karst gorge region, B. Soil Water Conservation, 23, 19-22, 2003.

Zhang, Z., Fu, W., Zhang, H., Xiao, J. H., and Ma, K.: Study on soil erosion of different degrees in karst region by using cesium-137 technique, J. Mt. Sci., 25, 302-308, 2007.

Zhao, G., Mu, X., Wen, Z., Wang, F., and Gao, P.: Soil erosion, conservation, and Eco-environment changes in the Loess Plateau of China, Land Degrad. Dev., 24, 499-510, doi:10.1002/ldr.2246, 2013.

Zhou, N., Li, C., Jiang, S., Liu, G. M., and Long, X. H.: Models of soil and water loss and soil leakage in puding karst area, Bulletin of Soil and Water Conservation, 29, 7-11, 2009.

Zhu, X., Zhang, L., Fang, J., Zhao, Y. G., and Xiao, P. Q.: Research on simulated rainfall experiments of sediment yield in the processes of soil water erosion on sloping field, B. Sci. Technol. Soc., 25, 680-683, 2009.

Ziadat, F. M. and Taimeh, A. Y.: Effect of rainfall intensity, slope and land use and antecedent soil moisture on soil erosion in an arid environment, Land Degrad. Dev., 24, 582-590, doi:10.1002/ldr.2239, 2013. 